\title{
3D Modelling from New and Existing Gravity Data of an Intrusive Body in the Northern Part of Kribi-Campo Sub-Basin in Cameroon
}

\author{
Kue Petou Rokis Malquaire ${ }^{1,2^{*}}$, Owona Angue Marie Louise ${ }^{3,4^{*}}$, Njingti Nfor $^{2,3}$, \\ Manguelle-Dicoum Eliezer ${ }^{4}$ \\ ${ }^{1}$ National Institute of Cartography, Yaoundé, Cameroon \\ ${ }^{2}$ Postgraduate School of Sciences, Technologies \& Geosciences, University of Yaoundé I, Yaoundé, Cameroon \\ ${ }^{3}$ Department of Physics, Advanced Teacher Training College, University of Yaoundé I, Yaoundé, Cameroon \\ ${ }^{4}$ Department of Physics, Faculty of Science, University of Yaoundé I, Yaoundé, Cameroon \\ Email: *rokis.petou@yahoo.fr, *mlasseowona@yahoo.fr
}

How to cite this paper: Malquaire, K.P.R., Louise, O.A.M., Nfor, N. and Eliezer, M.-D. (2017) 3D Modelling from New and Existing Gravity Data of an Intrusive Body in the Northern Part of Kribi-Campo SubBasin in Cameroon. International Journal of Geosciences, 8, 984-1003.

https://doi.org/10.4236/ijg.2017.88056

Received: June 23, 2017

Accepted: August 19, 2017

Published: August 22, 2017

Copyright $\odot 2017$ by authors and Scientific Research Publishing Inc. This work is licensed under the Creative Commons Attribution International License (CC BY 4.0).

http://creativecommons.org/licenses/by/4.0/

\begin{abstract}
A new gravity survey was carried out in the northern part of the onshore Kribi-Campo sub-basin in Cameroon. The data were incorporated to the existing ones and then analyzed and modeled in order to elucidate the subsurface structure of the area. The area is characterized in its north-western part by considerably high positive anomalies indicative of the presence of a dense intrusive body. We find, 1) from the analysis of the gravity residual anomaly map, the high positive anomalies observed are the signature of a shallow dense structure; 2) from the multi-scale analysis of the maxima of the horizontal gradient, the structure is confined between depths of $0.5 \mathrm{~km}$ and $5 \mathrm{~km}$; 3) from the quantitative interpretation of residual anomalies by spectral analysis, the depth to the upper surface of the intrusive body is not uniform, the average depth of the bottom is $\mathrm{h}_{1}=3.6 \mathrm{~km}$ and the depths to particular sections of the roof of the intrusion are $h_{2}=1.6 \mathrm{~km}$ and $\left.h_{3}=0.5 \mathrm{~km} ; 4\right)$ and the $3 \mathrm{D}$ modeling gives results that are suggestive of the presence of contacts between rocks of different densities at different depths and a dense intrusive igneous body in the upper crust of the Kribi zone. From the 3D model the dense intrusive igneous block is surrounded by sedimentary formations to the south-west and metamorphic formations to the north-east. Both formations have a density of about $2.74 \mathrm{~g} / \mathrm{cm}^{3}$. The near surface portions of this igneous block lie at a depth range of $0.5 \mathrm{~km}$ to $1.5 \mathrm{~km}$ while its lower surface has a depth range of $3.6 \mathrm{~km}$ to $5.2 \mathrm{~km}$. The shape of the edges and the bottom of the intrusive body are suggestive of the fact that it forms part of a broader structure underlying the Kribi-Campo sub-basin with a great influence on the sedimentary cover.
\end{abstract}




\section{Keywords}

Kribi-Campo Sub-Basin, Gravity Data, 3D Modelling, Spectral Analysis, Residual Anomaly

\section{Introduction}

According to [1], the Aptian salt basin of Equatorial West Africa is a combination of seven basins among which are the Rio del Rey and the Douala/Kribi-Campo basins. The Doula/Kribi-Campo basin has two sub-basins: the Douala sub-basin to the North and the Kribi-Campo sub-basin to the South. The Kribi-Campo sub-basin is located between $2^{\circ} 20^{\prime} \mathrm{N}$ and $3^{\circ} 20^{\prime} \mathrm{N}$, and extends over $6150 \mathrm{~km}^{2}$ offshore and $45 \mathrm{~km}^{2}$ in a triangular onshore area [2]. It is limited to the South by the Campo high, to the east by the Precambrian basement, and to the North by a possible Aptian salt and/or the northern end of the Kribi Fracture Zone noted Kribi FZ (Figure 1). The western limit of the sub-basin seems to be broadly defined by the Kribi Fracture Zone [2]. The area of study is part of the Precambrian of central and southern Cameroon which shows many geological features of different ages and varying petrographic characteristics [3]. The green rock belts (GRB) and gneiss are part of a geological unit called "Nyong Unit"

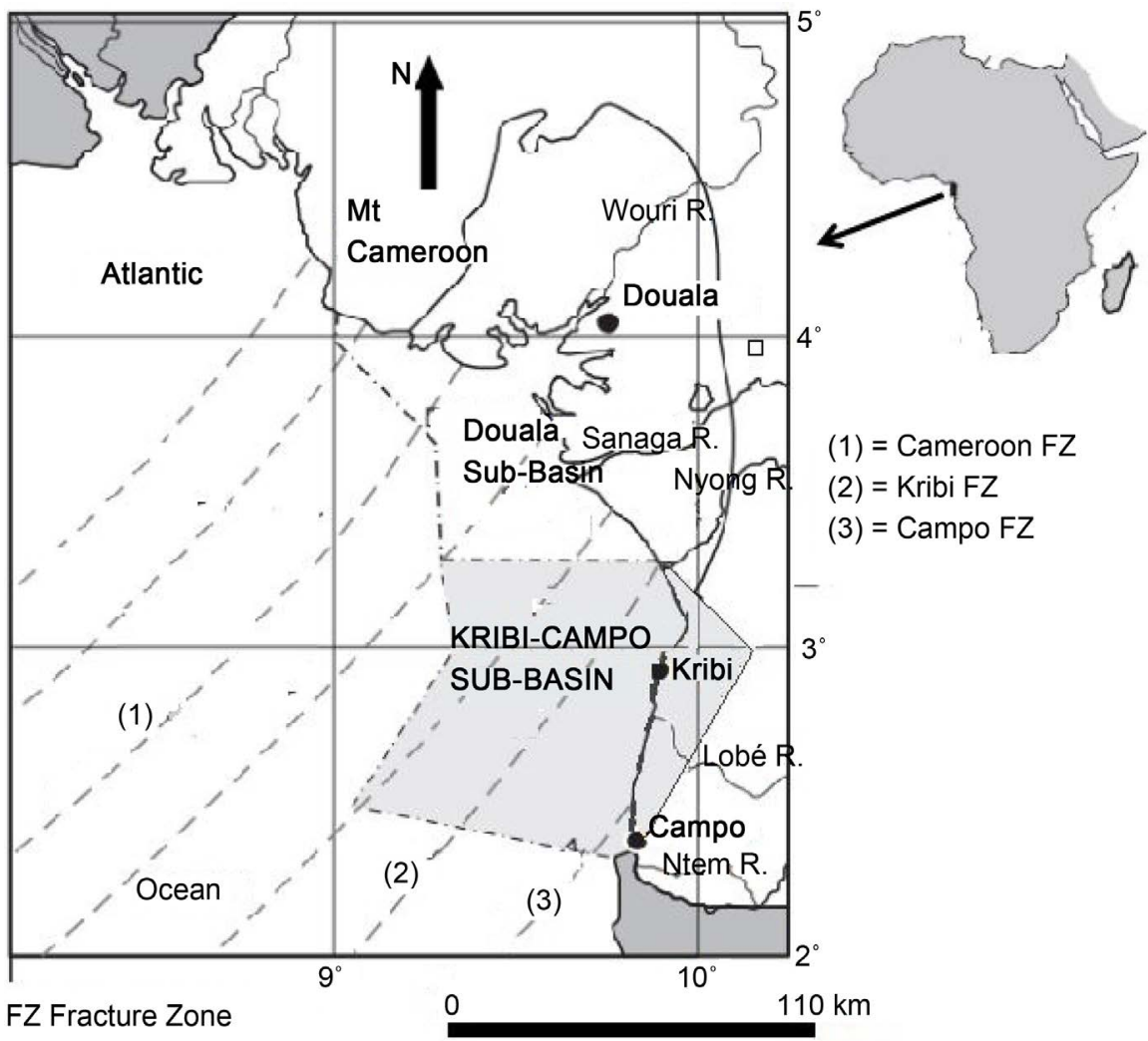

Figure 1. Location of the Kribi-Campo sub-basin in Cameroon (West Africa) between the main fractures of the Cameroon margin (modified after [2]). 
which covers a greater part of the study area. The other part of the area is covered by sediments; Metagranodiorite, and Metamorphic rocks of the Yaounde Group, which are part of the Ntem Unit. Until now, oil and gas production and exploration are focused on the offshore portion of the sub-basin. But recent studies are suggesting the possibility of the presence of oil, gas and minerals in the onshore portion [4]. We focus this study on the Kribi-Campo sedimentary basin (especially on the onshore area) to bring more light on the understanding of the basement in that region, and therefore contribute to the identification of potential mining areas of the basin. Gravity investigations conducted by [3] [4] [5] [6], have indicated the presence of dense or basic intrusive bodies within the main formation broadly characterized by the high intensity gravity anomaly observed in the Kribi area. The objective of this study is to conduct a 3D modelling from a combination of new and existing gravity data of an intrusive body responsible for the high anomalies observed in the northern part of Kribi-Campo sub-basin in order to understand its structural layout. From the 3D gravity model derived, new insights of the Kribi-Campo region are provided, along with the structural characterization of this Kribi-Campo intrusive body and the inference of its geometry. The model obtained highlights the mechanism of deep tectonic activity at the transition zone in general and the Kribi-Campo basin in particular, which is related to the setting of the basin.

\section{Geological and Tectonic Settings}

\subsection{Geological Settings}

The Kribi-Campo sub-basin, is a sedimentary basin which lies both onshore and offshore on the cost of Cameroon between latitudes $2^{\circ} 20^{\prime} \mathrm{N}-3^{\circ} 20^{\prime} \mathrm{N}$ and longitudes $9^{\circ} 15^{\prime} \mathrm{E}-10^{\circ} 00^{\prime} \mathrm{E}$ covering a total surface area of about $6195 \mathrm{~km}^{2}$ (Figure 1). The sub-surface of the Kribi-Campo sub-basin is mostly made up of Archean rocks of the Ntem complex recovered by the Paleoproterozoic rocks of the Nyong Unit [7].

The northern area of the basin is occupied by the Oubanguide Belt which consists of Precambrian rocks that were remobilized by the Panafrican episode (600 to $500 \mathrm{Ma}$ ). These rocks are mainly schists and gneisses that have been intruded by granites and diorites [8] [9].

The southern domain of the basin is occupied by the northern edge of the Congo craton, represented by the Ntem complex which consists predominantly of Precambrian rocks of granulite facies formed during the Archean and rejuvenated during the Eburnean orogeny. The Ntem Complex also carries imprints of past magmatic activities, which are characterized by several occurrences of dense rocks such as gabbros [9] [10].

The coastal area of the basin is composed of Cretaceous sediments, mostly sandstones and small amounts of limestone and shales [9]

\subsection{Tectonic Settings}

Many studies, [3] [5] [9] carried out in the transition zone between the Congo 


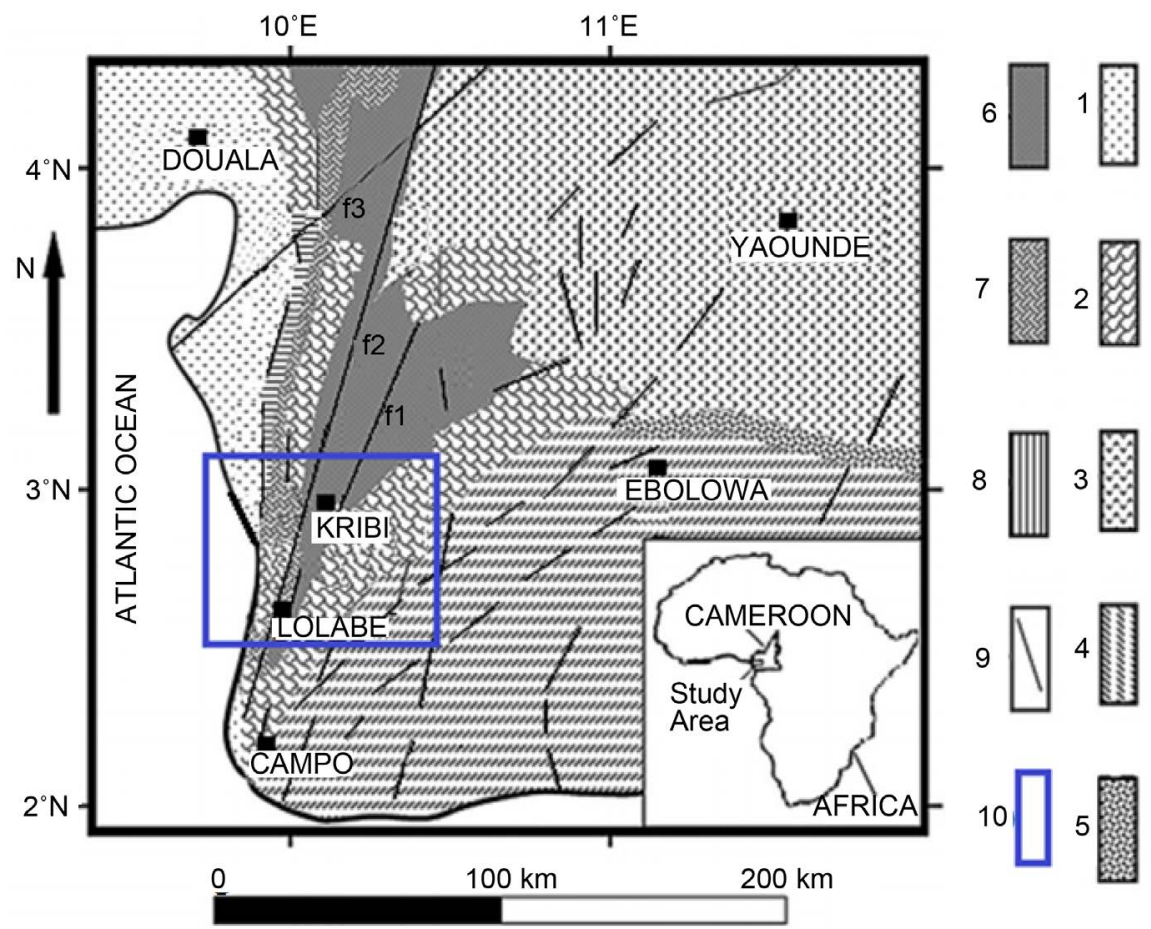

Figure 2. Location and simplified geological map of the region (modified after [18]). 1: sediments; 2: gneiss; 3: Yaounde Group; 4: Ntem Complex; 5: tonalites; 6: green rock belts; 7: metamorphic rocks of the Yaounde Group, 8: metagranodiorite; 9: faults; 10: study area (2, 6, 7 and 8 are geological formations included in a geological unit called "Nyong Unit").

craton and the Oubanguide belt have reported that the northern margin of the Congo Craton resulted from a convergent collision with the Panafrican Mobile Belt (PMB), which has been thrusted southwards onto the Craton. These same studies revealed that the area mainly underwent brittle deformations related to multistage compressional and extensional tectonics that give rise to major faults. These are mainly characterised by the Kribi-Campo Fault (KCF) system which is herein defined as a continuation of the Sanaga Fault [3] [4] [9] [11] [12]. Other studies [13] [14] supported by [15] also link the KCF to an offshore fault system known as the Kribi Fracture Zone inferred as the eastern end of the Ascension Fracture Zone settled during the Cretaceous break-up of Gondwana and the separation of Africa from South America. This gave rise to the development of the Kribi-Campo sub-basin. [16] showed, through joint inversion of Rayleigh waves over the entire Cameroon, that the thickness of the upper crust in the South of Cameroon varies in general between 10 and $20 \mathrm{~km}$.

\section{Material and Methods}

\subsection{Gravity Data}

The gravity data used in this work are the combination of new and existing data. The existing data were collected during gravity surveys of central Africa by ORSTOM and referenced in [17]. These data were collected using Worden gra- 
vimeters $\left(\mathrm{N}^{\circ} 313\right.$ and 600$)$ with a station-spacing of 4 to $5 \mathrm{~km}$. This first dataset is made up of 186 gravity stations. Due to the high station-spacing and the absence of data in some areas, we conducted a gravity campaign in the KribiCampo-Ma'an area (this area had not been subject to any ground geophysical survey before this campaign) in March 2015, using a Lacoste \& Romberg G-823 gravimeter.The difference of the gravity data distribution from the ORSTOM geophysical survey and our team is induced by the fact that, during the period when ORSTOM survey was carried out (1962) very few roads where available and some areas could not be accessible. Today, with the few progress in roads infrastructures, we have access to more sites even though the zone is located in the dense equatorial forest and the Campo National park where only open field roads are accessible. The survey data constitute 223 gravity data points with a station-spacing of 0.5 to $2 \mathrm{~km}$. Free-air correction, luni-solar tidal correction, Terrain correction and instrumental drift correction were applied on these recent measurements and the Bouguer anomalies were derived.

Putting these new and existing data points together, gives a total of 409 gravity data points.

Free-air and Bouguer reductions based on a mean density of $2.67 \mathrm{~g} / \mathrm{cm}^{3}$ were applied on the data and the simple Bouguer anomalies derived. The resulting Bouguer anomalies as shown in Figure 3 constitute the dataset that is used in

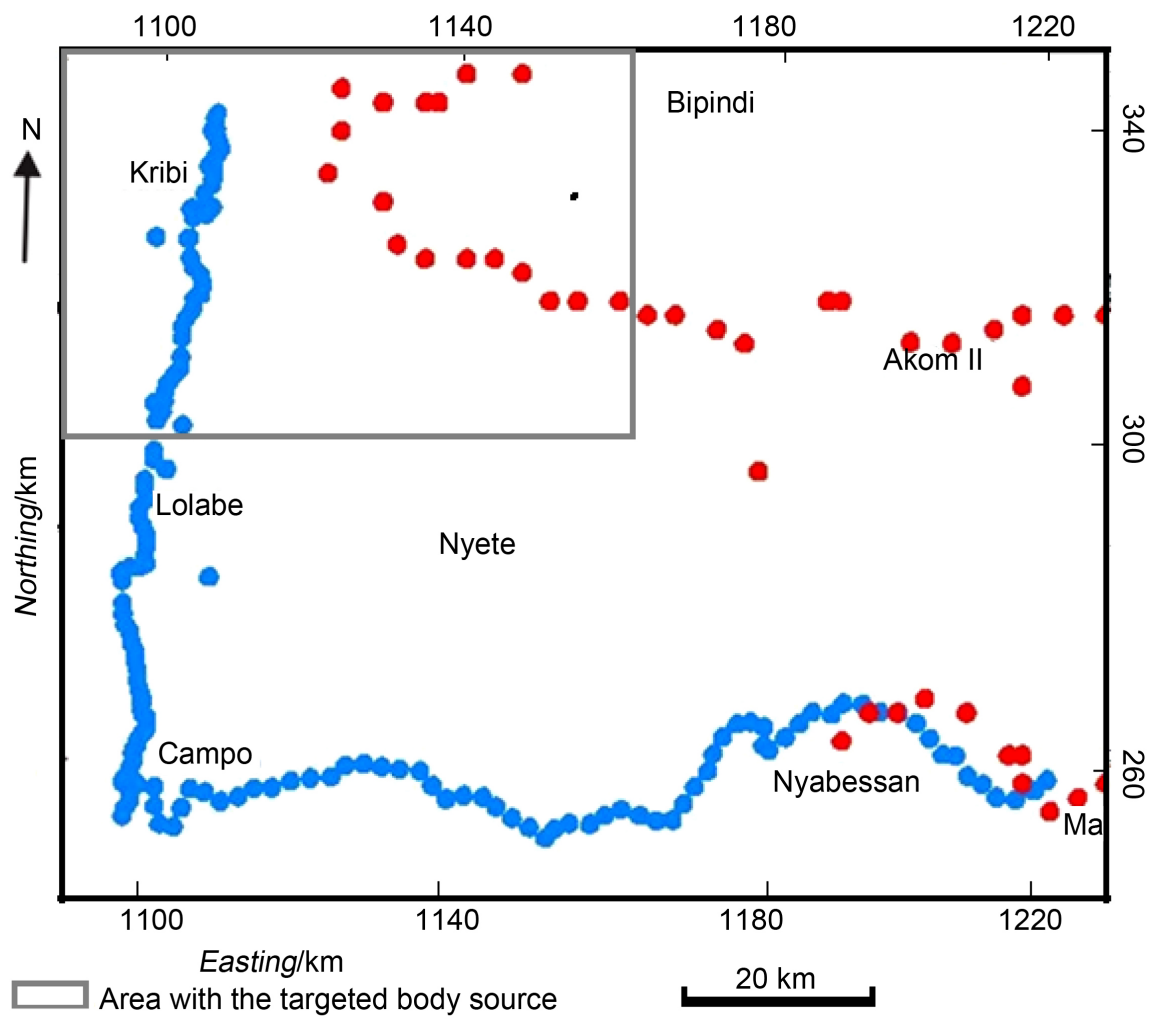

Figure 3. Gravity data distribution map showing the area where the targeted body is located. The red dots represent the data from the ORSTOM geophysical survey (1965) while the blue dots represents the recently collected data in the region by our team. 
the context of the present study. The Kriging method was applied on the gravity data for interpolation using kriging gridding algorithm implemented in Oasis Montaj 8.0 software. The maximum value of the Bouguer anomaly in the grid is $-68.7 \mathrm{mGal}$ while the minimum value is $-2.0 \mathrm{mGal}$. Figure 3 shows the distribution of the data points, new and existing ones, in the study area.

\subsection{Methodology}

In order to delineate the structures of the subsurface in our study area, two main approaches have been used namely:

- the maxima of the horizontal gradient upward continued to locate the anomalous body in the subsurface,

- the spectral analysis to determine the average depth of this body source.

Results of these methods, coupled with previous findings in the area [6] [19] and available geological information confirmed the existence of an anomalous body in the area, to which 3D modelling has been applied.

\subsubsection{The Horizontal Gradient and Upward Continuation}

According to [20], coupling the horizontal gradient with upward continuation allows to locate the discontinuities and the determination of their dip.

The horizontal gradient is an operation that measures the rate of change of a potential field in the $x$ and $y$ directions [21] in order to image subsurface structures. However, the total horizontal gradient magnitude (HGM) is preferred for its simplicity. The $H G M$ operator is defined by the relation below:

$$
\operatorname{HGM}(x, y)=\sqrt{\left(\frac{\partial G}{\partial x}\right)^{2}+\left(\frac{\partial G}{\partial y}\right)^{2}}
$$

where $G$ is the Bouguer gravity field.

The works of [21] [22] showed that the maxima of the horizontal gradient of gravity anomalies help locate contacts associated with abrupt changes in density, which are interpreted either as faults, geological contacts or intrusions. Faults are expressed by a quasi-linear disposition of at least three maxima and horizontal limits of intrusive bodies are shown by quasi-circular disposition of many maxima. The multi-scale analysis of the horizontal gradient consists in creating a series of analytical upward continuations of gravity data. The horizontal gradient is then computed for every height and its maximum is determined. To determine the direction of dip of the contacts highlighted, it is assumed that the more the gravity data is upward continued, the more the deeper structures are emphasized [4]. In fact, when the contact presents a dip, the maxima of horizontal gradients are displaced progressively down the dip as the height of upward continuation is increased. But in the case of sub-vertical contacts, these maxima remain practically at the aplomb [19].

\subsubsection{Spectral Analysis Method}

This method is carried out through 2D Fast Fourier Transform which trans- 
forms gravity data from the space domain to the wavenumber domain to estimate the depths of the structures responsible for the measured anomaly. It has been used extensively by many authors, namely [23] [24] [25].

The finite discrete Fourier transform is given by the equation:

$$
B(\omega)=\sum_{0}^{N-1} b(x) \exp (-i \omega x) \cdot \Delta x
$$

where $b(x)$ represents the discrete $\mathrm{N}$ data array of gravity data obtained by sampling a continuous profile at evenly spaced intervals $\Delta x$. $i$ is the complex operator, $\omega=2 \pi k$ is the spatial frequency and $k=\lambda^{-1}$ is the wavenumber in the $x \mathrm{di}$ rection.

The expression of the Bouguer Slab Effect is then given by the equation:

$$
B(k)_{z=0}=2 \pi \Delta \rho G \cdot \exp (-2 \pi k t) \cdot F(k)_{z=0}
$$

where $B(k)_{z=0}$ is the Fourier transform of the Bouguer anomaly profile $b(x)_{z=0} ; \Delta \rho$ is the density contrast between two layers; $F(k)$ is the Fourier transform of $f(x)$, the derivation of the interface from the mean depth $z$, $G$ is the gravitational constant. The mean depth can then be calculated using the following equation:

$$
h=\frac{\Delta \log E}{4 \pi \Delta k}
$$

where $E$ is the power spectrum of $B(k)$.

The square of the Fourier amplitude spectrum is plotted versus the radial frequency. The slope of the relationship between the wave number of the gravity field and the logarithmic power spectrum provide information about the depths of the source bodies.

\section{Results}

\subsection{Analysis and Interpretation of Gravity Data}

\subsubsection{Analysis of Bouguer Anomaly Map}

The Bouguer anomaly map presented in Figure 4 was obtained after an interpolation using a kriging gridding algorithm implemented in Oasis Montaj software. The highlight shows the most prominent anomalies within the study area. An overview of the map reveals three gravity domains:

The first domain which covers the western part of the map is characterized by high values of gravity anomalies. The form of these anomalies suggests that it marks the limit of a large structure to the left of the study area. In the field, this area corresponds to low altitudes and its position near the Atlantic Ocean shows that this anomaly has it source from highly dense rocks. This domain, with anomaly values ranging between $-40.1 \mathrm{mGal}$ and $-2.0 \mathrm{mGal}$ presents four prominent peaks, one at the Lolabe locality, another one in Kribi and the last two to the east of Kribi. All these peaks can be interpreted as high density or basic intrusive bodies within the main formation. The two peaks observable to the east of Kribi may be considered as a unique, very high-value anomaly, which according to [6] corresponds to a ring complex affected by a nearly N-S trending 


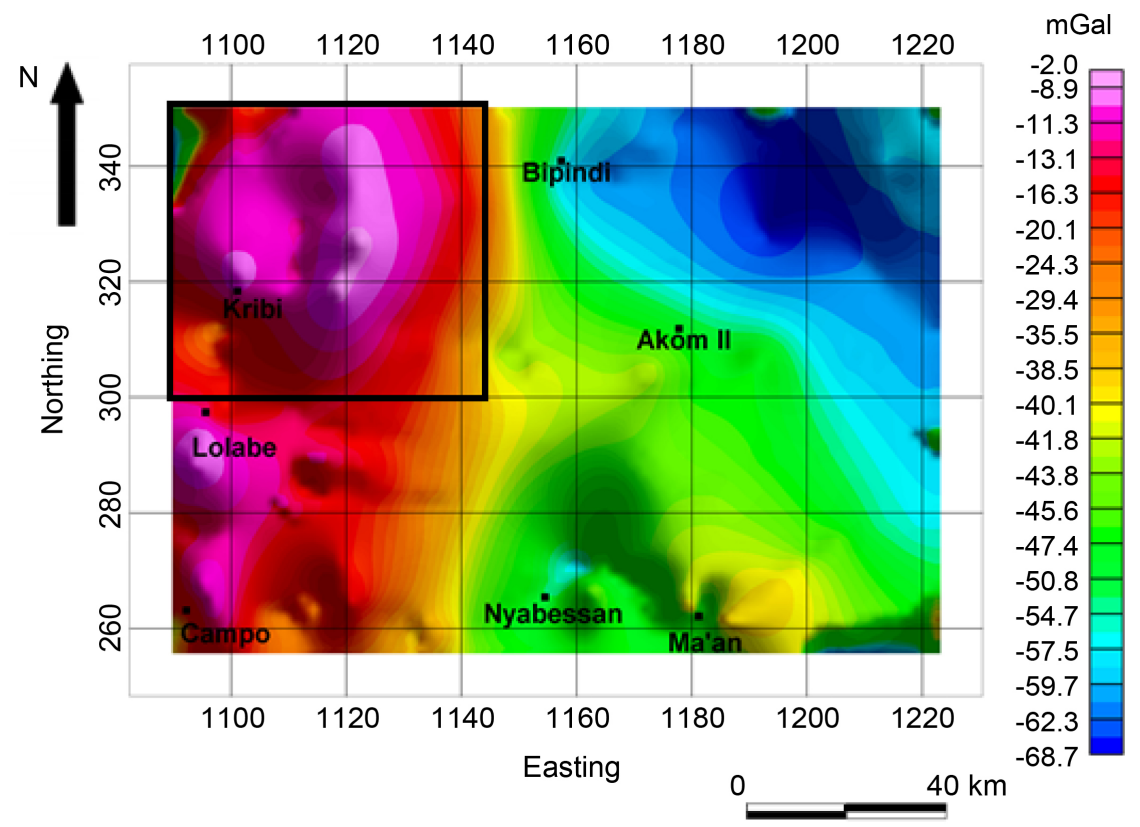

Figure 4. Bouguer anomaly map of the region showing the Kribi anomaly.

discontinuity.

The second domain, located at the northeastern side of the map displays two apparent ring shapes, characterized by very low amplitude anomalies trending NW-SE from Bipindi to the eastern part of Akom II, these anomaly values range from -68.7 to $-54.7 \mathrm{mGal}$. There are interpreted as due to the presence of intrusive low density bodies in the subsurface.

The third domain which is situated in the middle of the map, from Bipindi to Nyabessan, consists of average anomaly values ranging from $-50.9 \mathrm{mGal}$ to $-40.9 \mathrm{mGal}$ and is separated from the two other domains by high gradients marking discontinuities between two structures in the subsurface. The correlation with surface geology shows that this area is the signature of charnockites and green rock belts of the Ntem Unit.

\subsubsection{Analysis of Residual Anomaly Map}

The Bouguer anomalies are the combination of deep and shallow sources, a separation of these anomalies into regional (deep sources) and residual (shallow sources) components was carried out in order to clearly identify the anomaly sources. This separation was performed using the polynomial fitting method. The procedure computes the mathematical surface, which gives the best fit to the gravity field within specific limits [26]. This surface is considered to be the regional gravity anomaly. The residual is obtained by subtracting the regional field from Bouguer anomaly. The residual map of the study area presents characteristics similar to the Bouguer anomaly map. However, the high gravity ascribed to dense or basic intrusive bodies within the main formation and the low gravity ascribed to low densities intrusion are visibly more distinct on this residual gravity map. On the third order residual map shown in Figure 5, the three anomalous 


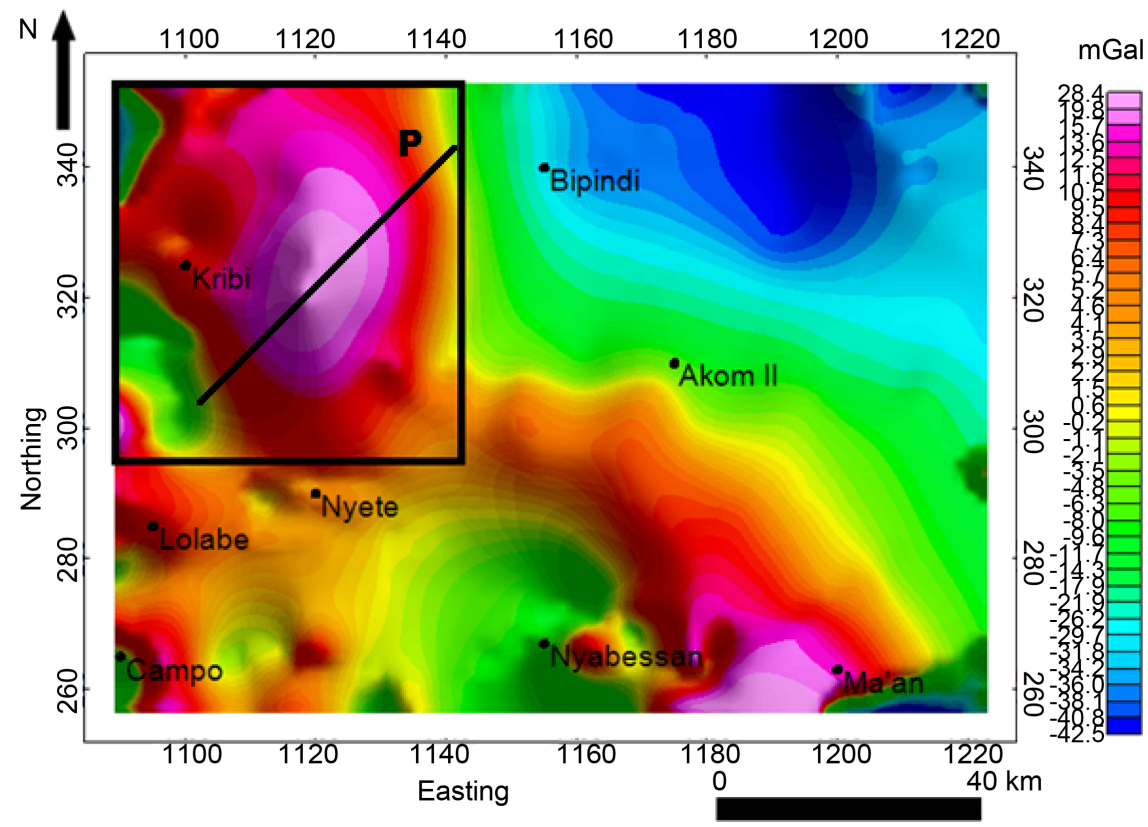

Figure 5. Third order residual anomaly map of the region showing the Kribi anomaly.

peaks observed around the Kribi area are seen to have merged to form a single oval peak indicating the prominence of the dense intrusive body at depth. At depth the characteristics of the structure surrounding this intrusive body extend southeastwards from Kribi to Akom II and become more pronounced again between Nyabessan and Ma'an. Since the effects of the mantle and lower crust are not of interest in this work, a third order residual anomaly is used for modelling in order to have a better chance of locating the depth to bottom of the dense intrusive body.

In order to determine the nature and shape of the Kribi intrusive body, the residual field obtained here will be studied using three methods namely: the multi-scale analysis of gradients method, which is usually employed for the analysis of the multi-scale residual anomalies; the spectral analysis method and the 3D modelling.

\subsection{The Local Maxima Map of the Horizontal Gradient of the Residual Anomaly}

After computing the horizontal gradient of the third order residual anomaly, the resulting map is upward continued at $0 \mathrm{~km}, 1 \mathrm{~km}, 2 \mathrm{~km}, 3 \mathrm{~km}, 4 \mathrm{~km}$ and $10 \mathrm{~km}$. The local maxima are then calculated and superimposed. The choice of the high of the upward continuation is determined by the types and depth of the structures that we intend to highlight. Given that, the higher we upward continue, the deeper the structures are highlighted. In our study, we intend to model a shallow formation. The maxima of the gradient of the residual anomaly upward continued could be observed on the map until the depth of $10 \mathrm{~km}$. after $10 \mathrm{~km}$, no effect of the anomaly featured on the map. That is why we choosed to stop at 10 
$\mathrm{km}$. The Maxima of the horizontal gradient of the third order residual anomaly map upward continued to $0 \mathrm{~km}, 1 \mathrm{~km}, 2 \mathrm{~km}, 3 \mathrm{~km}, 4 \mathrm{~km}$ and $10 \mathrm{~km}$ as presented in Figure 6 shows lines and quasi-circular contacts corresponding to horizontal limit of lineaments and intrusive bodies respectively. The depth of a lineament or an intrusive body is determined by the continued presence of the local maxima for increasingly high altitudes of upward continuation. This study will be focused on the continued presence of a quasi-circular contact noted (B1) in the Kribi area in the analyzed maxima of the horizontal gradient of the residual anomaly map upward continued to $0 \mathrm{~km}, 1 \mathrm{~km}, 2 \mathrm{~km}, 3 \mathrm{~km}, 4 \mathrm{~km}$ and $10 \mathrm{~km}$.

The vertical limits of such an intrusive body can be predicted by the method developed by [19], in which the depth of the top of the anomaly sources obtained after an upward continuation at the height $\mathrm{h}$ is greater than or equal to $\mathrm{h} / 2$, because the upward continuation at the height $\mathrm{h}$ eliminates the effect of the sources situated above the depth $\mathrm{h} / 2$. This implies in Figure 6 that the effects of the sources situated above the depth $0.5 \mathrm{~km}, 1 \mathrm{~km}, 1.5 \mathrm{~km}, 2 \mathrm{~km}$ and $5 \mathrm{~km}$ have been eliminated for the upward continuation to $1 \mathrm{~km}, 2 \mathrm{~km}, 3 \mathrm{~km}, 3 \mathrm{~km}, 4 \mathrm{~km}$, and $10 \mathrm{~km}$ respectively. The presence of green, red, yellow, blue and black contact on the western side of the intrusive body B1 indicates that the depth to bottom is between 2 and $5 \mathrm{~km}$. Also, the presence of green, red and yellow with the absence of black maxima on the eastern side of the contact indicates the depth to bottom here is between 1.5 and $2 \mathrm{~km}$. The results obtained from the analysis of the maxima map will be used to constrain the modelling of B1.

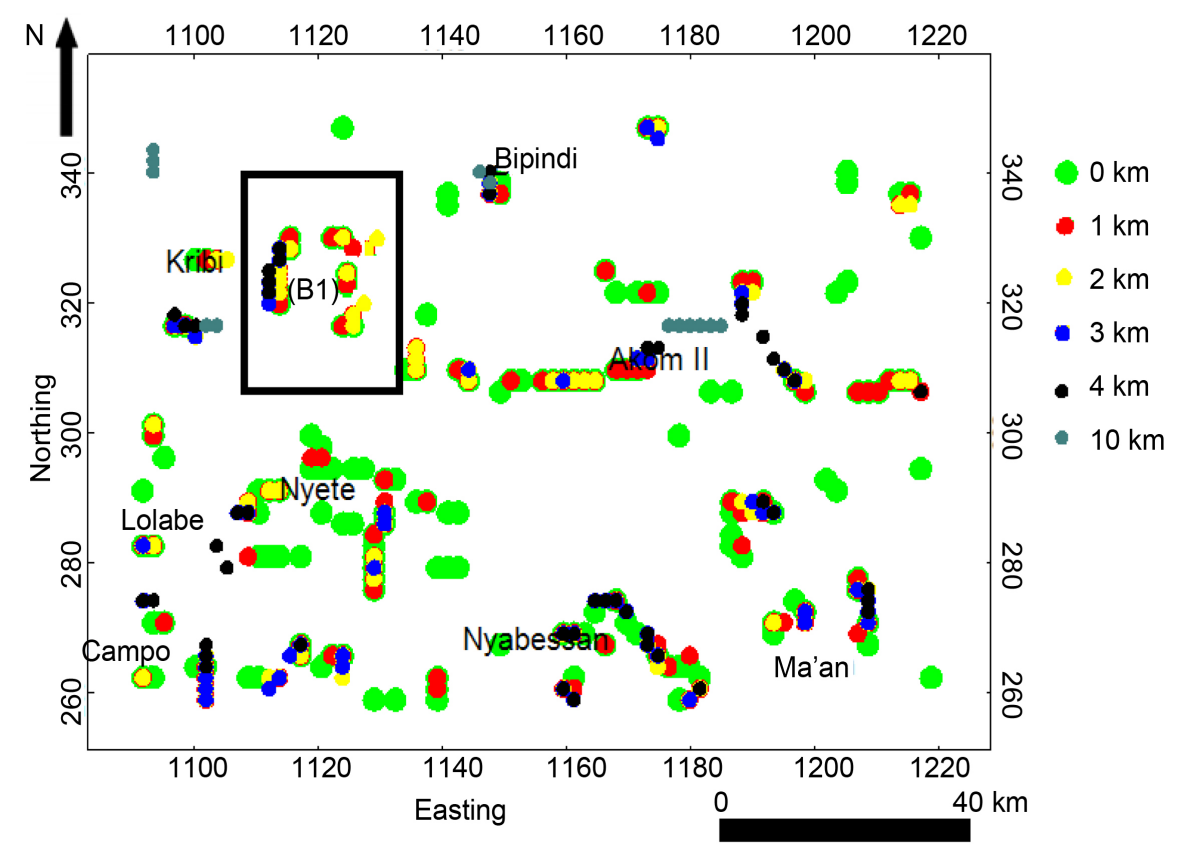

Figure 6. Superposition of the maxima of the gradients computed at various heights of upward continuation. Maxima are represented by small colored circles. The green, red, yellow, black and gray colors represent the maxima of the gradients upward continued at the heights of $0 \mathrm{~km}, 1 \mathrm{~km}, 2 \mathrm{~km}, 3 \mathrm{~km} 4 \mathrm{~km}$ and $10 \mathrm{~km}$ respectively. The located anomalous body source in the black frame. 


\subsection{Source Depth Estimation Using Spectral Analysis}

A profile $(\mathrm{P})$ was chosen and drawn on the third order residual gravity map. The data used to carry out the spectral analysis were from this profile shown by the black line crossing the main positive anomaly (Figure 5)

This profile was drawn with a NE-SW orientation and traversing through the suspected area of the intrusion.

Figure 7 shows the representation of the logarithm of the gravity power spectrum (energy E) with respect to wave number (spatial frequency) for the profile $P$. The curve obtained from this representation, made up of 9 points is observed to have three (3) slopes represented by the 3 colored lines fitted into the figure, each of which is obtained from 3 points. The depths obtained from the slope of the curve represent the average depths of the top of the anomalous source. This spectral graph presents three gradients that are used in determining the average depths $\mathrm{h} 1=3.6 \mathrm{~km}, \mathrm{~h} 2=1.6 \mathrm{~km}$ and $\mathrm{h} 3=0.5 \mathrm{~km}$ of interfaces of low, average and high spatial frequencies respectively. The resulted values observed on the graph suggest that the depth to the upper surface of the intrusive body B1 is not uniform. It is believed that $\mathrm{h} 1$ presents the average depth of the bottom of $\mathrm{B} 1$, while $\mathrm{h} 2$ and $\mathrm{h} 3$ are depths to particular sections of the roof of the intrusion. These values obtained using spectral analysis will serve as constraints for the modelling of the body.

\subsection{Direct Modelling}

3D modelling was carried out using GRAV3D software on the residual field with the aim of delineating and caracterizing the dense intrusive body responsible for the observed gravity anomalies in the study area. The GRAV3D library consists of three major programs and one utility. The facilities include: GM-DATA-

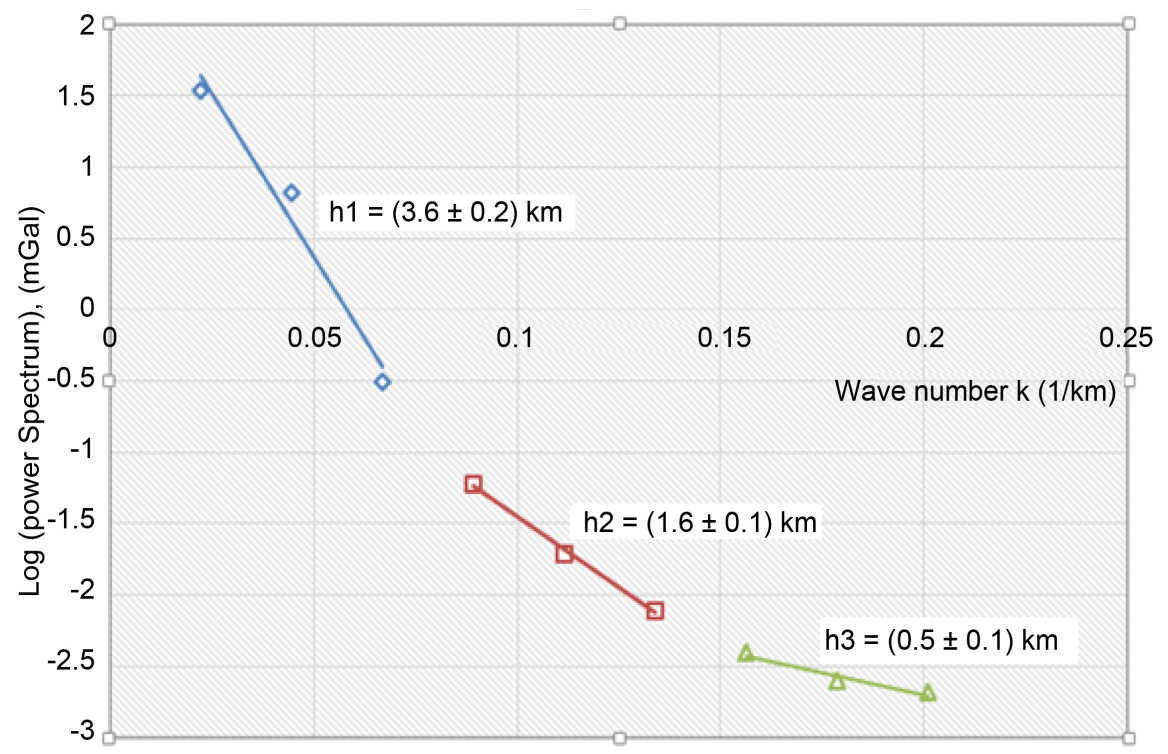

Figure 7. Logarithm of gravity power spectrum of profile $P$ of the third order residual anomalies plotted versus the wave number $k$. 
VIEWER: this utility was used for viewing the observed gravity data, error distributions, and for comparing observed to predicted data directly or as difference maps; MESHTOOLS3d: this utility was used for displaying resulting 3D models as volume renderings.

The modelling process of the intrusive body consist of constructing the body block by block in a predefined mesh. Every block is a combination of cubeoids of the same volume. Every block, with a constant density is defined along a vertical axis and along a horizontal axis. The coordinates of the blocks have been given taking as origin the point $\mathrm{O}(1095,300,0)$ bring latitude, longitude and altitude respectively all in kilometers. The body was constructed taking into account all the results provided by the multi-scale analysis of the maxima of gradients and spectral analysis.

After constructing the body, we used the GRAV3D program to calculate the gravity signature of the body, this signature is presented in the form of a map. This map is then compared with the map obtained from the observed gravity data. The best model is the one for which the two maps can approximately be superposed.

Figure 8 presents the map for the observed gravity data, obtained by plotting 254 data points from the study area using the GM-DATA-VIEWER utility of the GRAV3D software. The experimental residual anomaly map from 244 data points computed by the software is presented in Figure 9. It is observed that the two maps can approximately be superposed.

The intrusive body was depicted to be located between the depths of $0.5 \mathrm{~km}$ and $2 \mathrm{~km}$ from the surface on its Eastern side and between $0.5 \mathrm{~km}$ and $5 \mathrm{~km}$ on its Western side. The result provided by the spectral analysis, giving the depth to

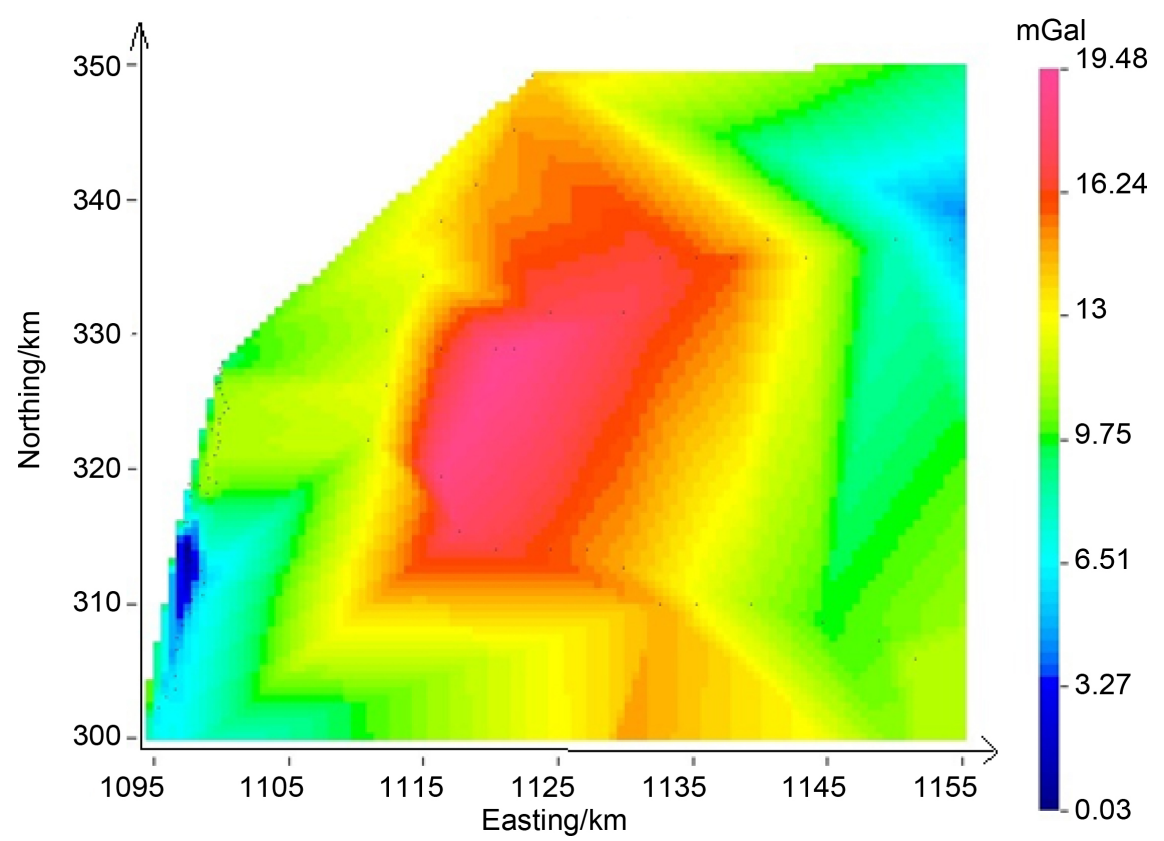

Figure 8. Observed residual anomaly map from 254 data points. 
the top of the Kribi intrusive body was also considered.

The various views of the 3D model of the Kribi intrusive body are presented in Figures 10-15. These models consist of a major block having a density of 2.74

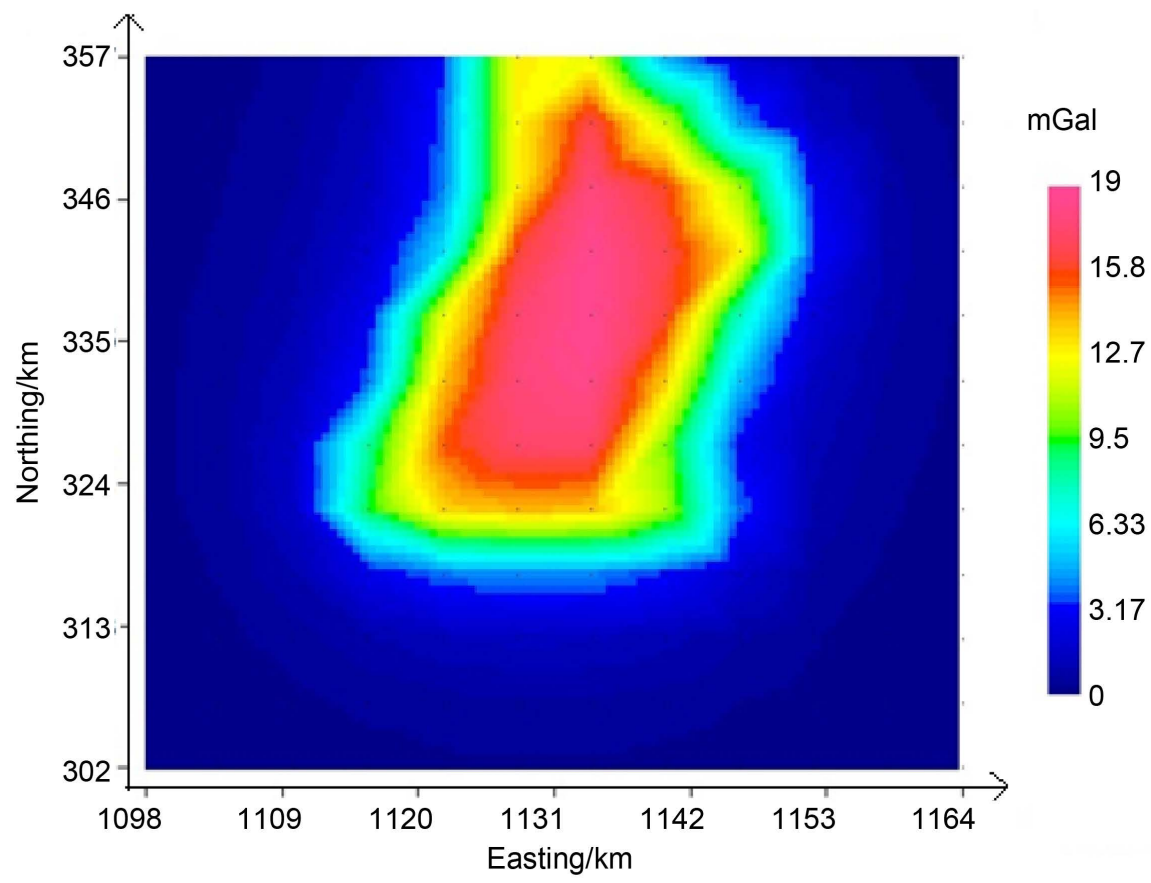

Figure 9. Experimental residual anomaly map from 244 data points.

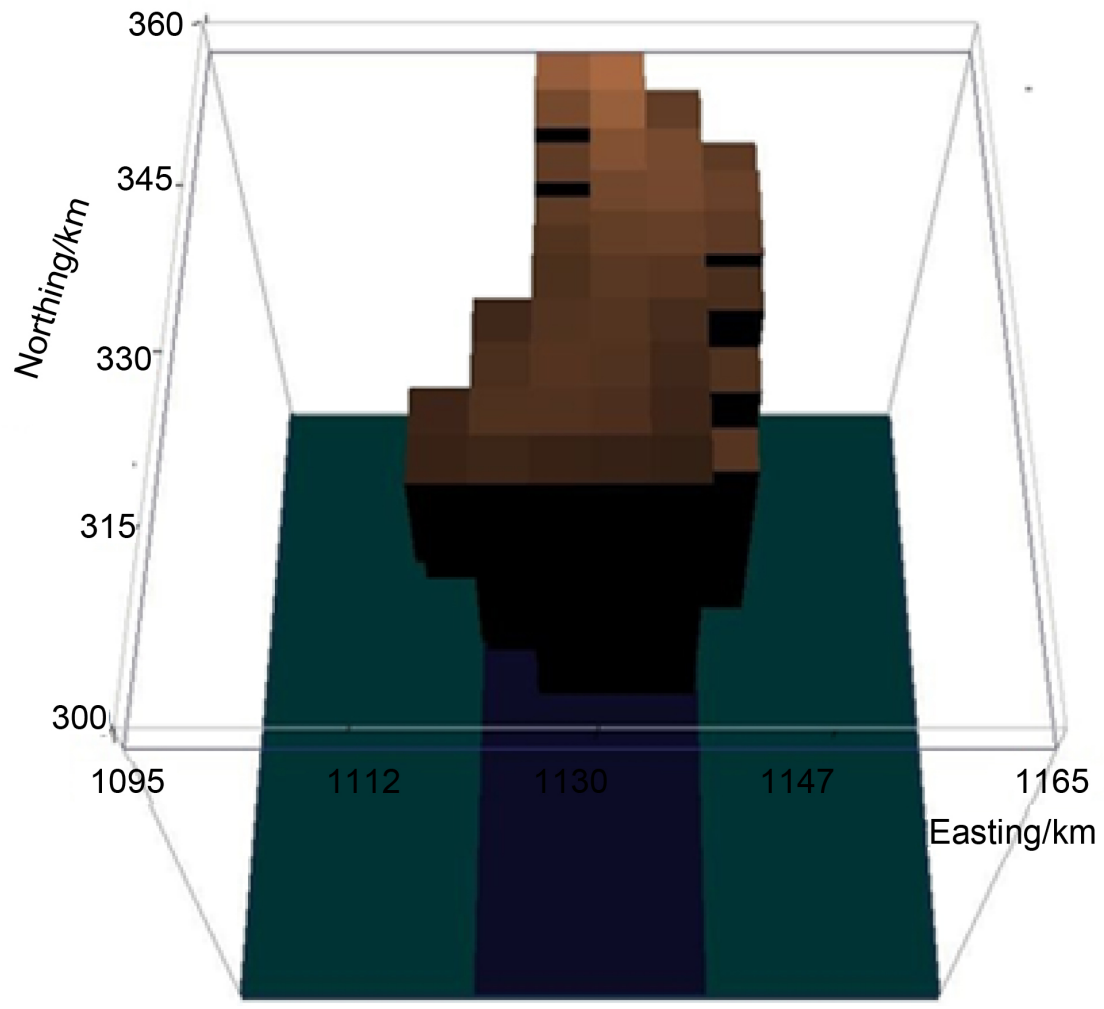

Figure 10. 3D model of the Kribi dense intrusive body as viewed from above. 


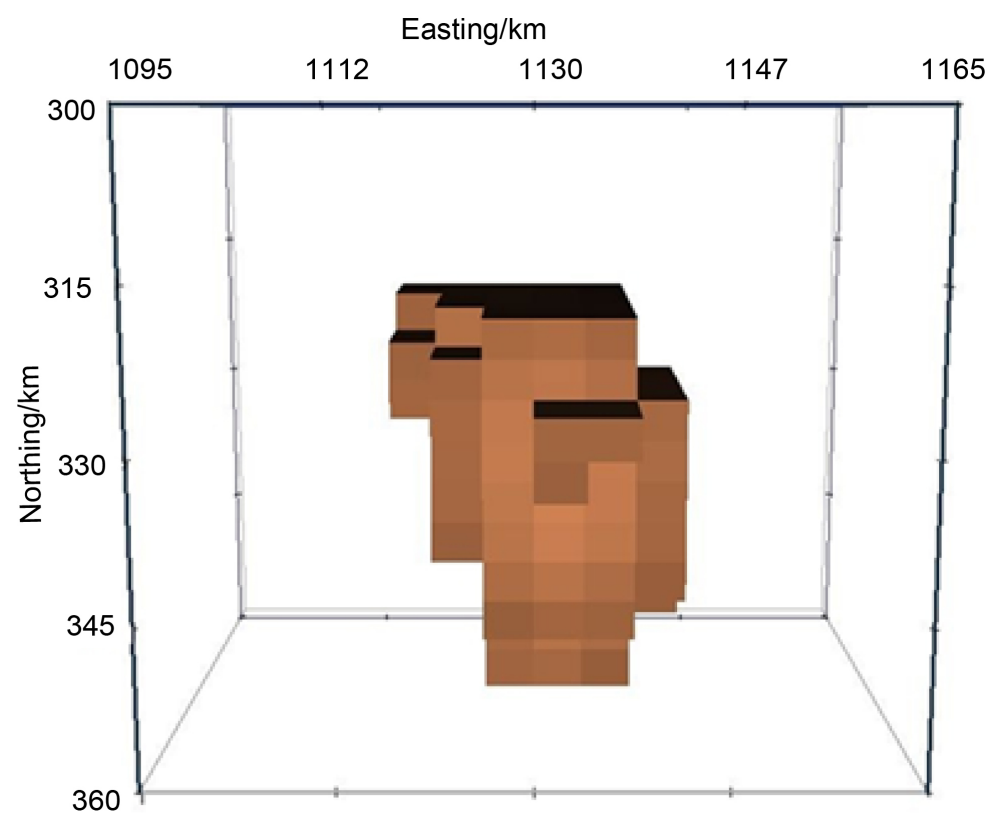

Figure 11. 3D model of the Kribi dense intrusive body as viewed from below.

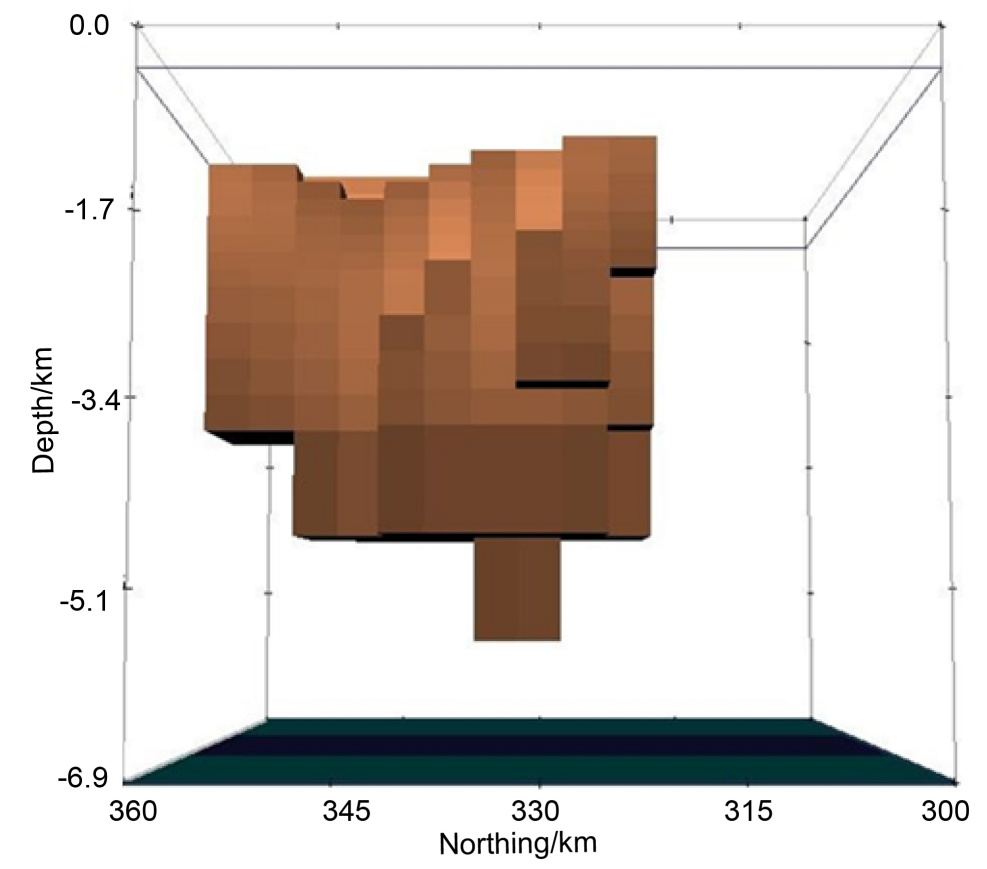

Figure 12. 3D model of the Kribi dense intrusive body as viewed from the West.

$\mathrm{g} / \mathrm{cm}^{3}$, a depth from the ground surface varying between $0.5 \mathrm{~km}$ and $1.5 \mathrm{~km}$. The latitudinal and longitudinal extensions of the body are about $12 \mathrm{~km}$ and $30 \mathrm{~km}$ respectively. Figure 12, Figure 14 and Figure 15 show that the general base of the body is situated at the depth of $4.8 \mathrm{~km}$ from its surface and its middle part extends to about $5.2 \mathrm{~km}$. The upper surface of this modelled body has a trapezoid shape while its other facades are more or less defined. 


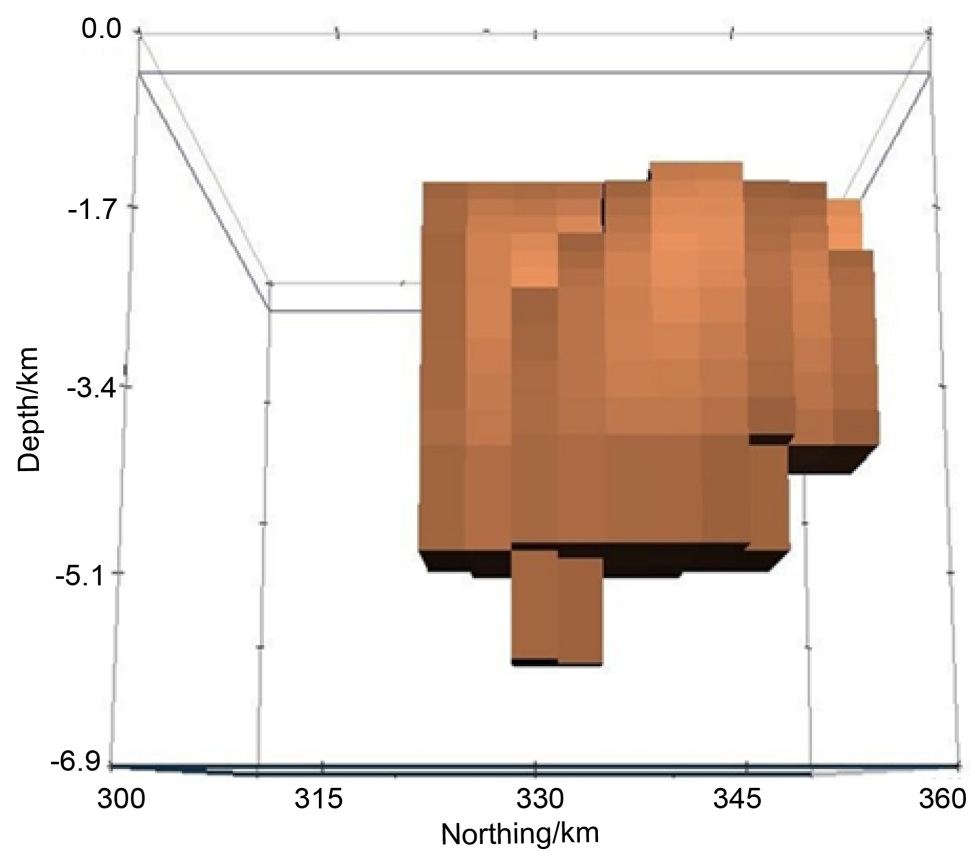

Figure 13. 3D model of the Kribi dense intrusive body as viewed from the East.

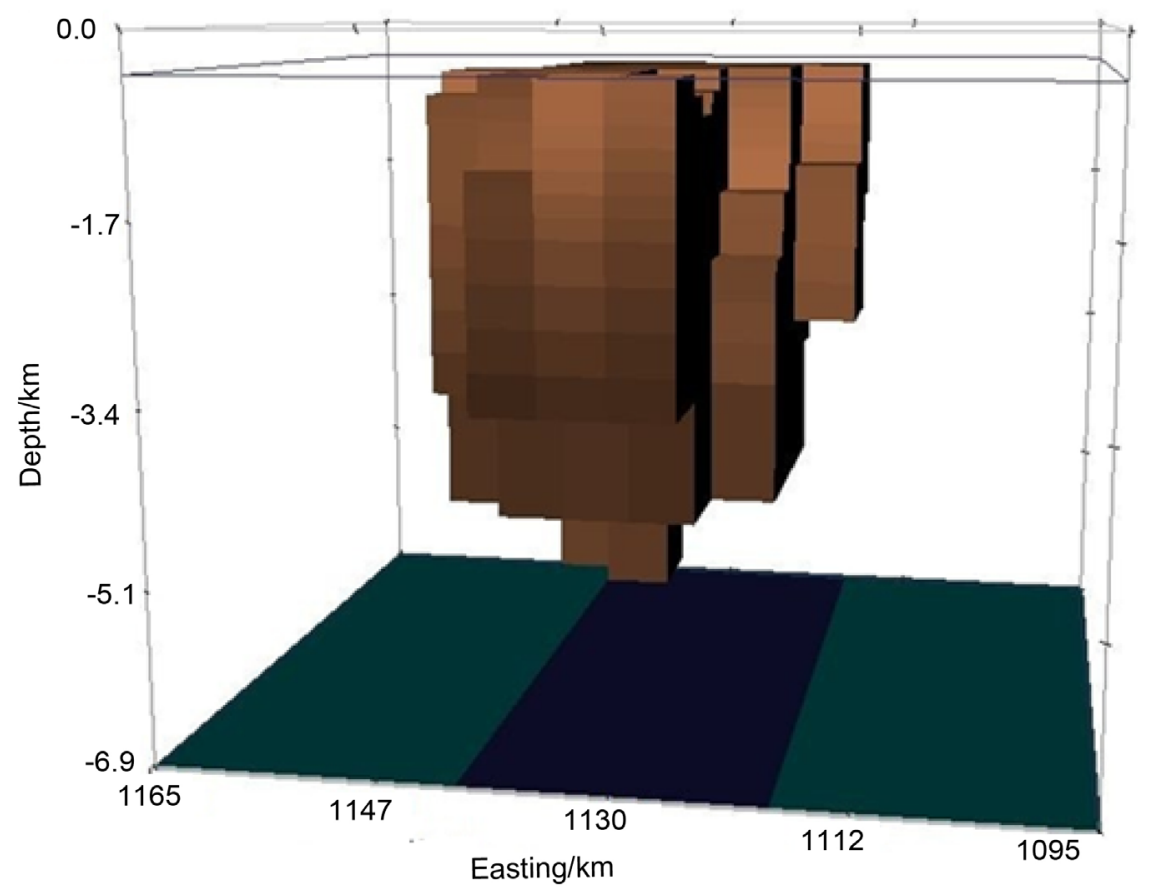

Figure 14. 3D model of the Kribi dense intrusive body as viewed from the North.

\section{Discussion}

The forward modelling of gravity data can have many models developed from an anomaly. In order to obtain a model that best reflects the subsurface structure, one has to consider certain parameters that would limit this uncertainty. As part of the constraints, the multi-scale analysis of the maxima of the horizontal 


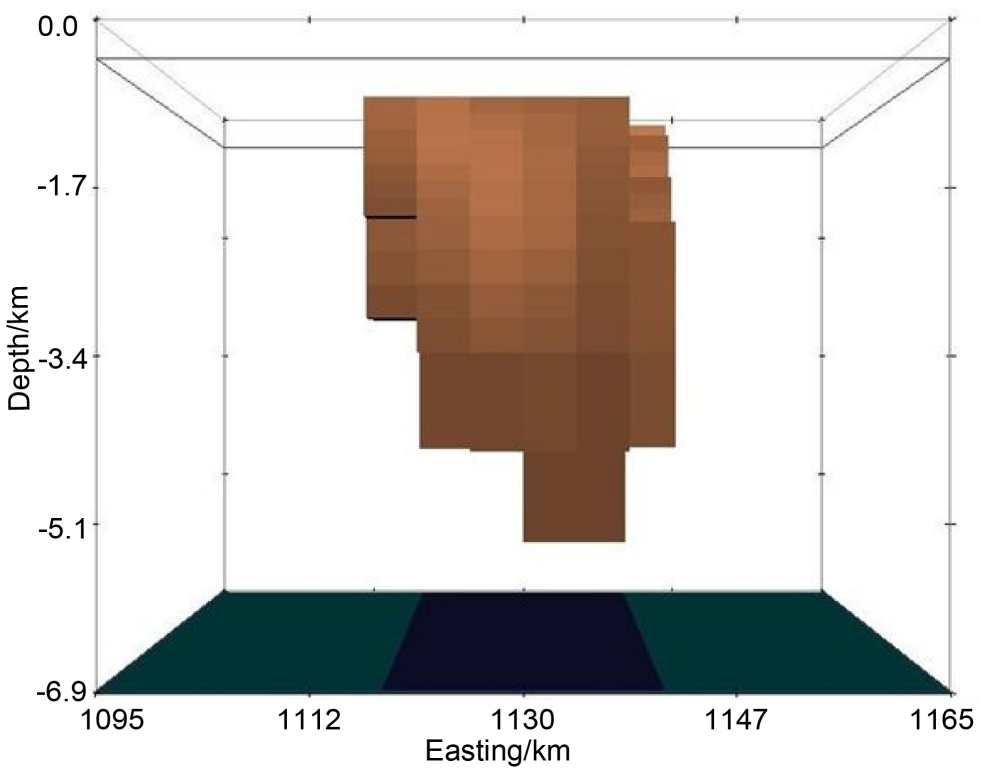

Figure 15. 3D model of the Kribi dense intrusive body as viewed from the South.

gradient of the third order residual anomaly has been used to locate and determine the depth range of the anomalous body. The spectral analysis has also been used to determine the average depths to the tops and bottoms of the anomalous body. It is observed that the depth varies between $0.5 \mathrm{~km}$ and $5 \mathrm{~km}$ from the surface of the earth. These constraints give an assurance of the validity of the model. The parameters of the model (depth to the top of $0.5 \mathrm{~km}$ and 1.5 for some sections of the body, and depth to the bottom of $4.8 \mathrm{~km}$ and $5.2 \mathrm{~km}$ for a slide section of the center of the body) are in accordance with the results obtained by [6] giving the depth range of the anomaly sources of Kribi between 0 and $6 \mathrm{~km}$. They also agree with the results of the multi-scale analysis of the maxima of gradient which situates the depth of the intrusive body between 0.5 $\mathrm{km}$ and $5 \mathrm{~km}$. However, there is a slide shift of the depth of the center of the body that extends to $5.2 \mathrm{~km}$ approximately. This value also agrees with the results provided by the spectral analysis method which give the average depth of the intrusive body between $0.5 \mathrm{~km}$ and $3.6 \mathrm{~km}$. The depth of $1.6 \mathrm{~km}$ obtained for some sections of the body by spectral analysis has been confirmed by the approximately $1.5 \mathrm{~km}$ obtained for particular sections of the roof of the body. The density of the body was evaluated to be about $2.74 \mathrm{~g} / \mathrm{cm}^{3}$. A superposition of the residual anomaly map with the geological map and previous studies [27] indicate that the intrusive rocks in the studied area are mainly gneiss, alkaline syenite, nepheline syenite, granodiorite, dolerite, tonalite and peridotites. [28] give the average density values for these rocks as presented in Table 1.

Given all these, the intrusive igneous body obtained by gravity modelling may be composed of gneiss, and granodiorite because their mean density is close to that of the modelled body. Assuming the value of the density of the surrounding metamorphic rocks to the North-East of $2.67 \mathrm{~g} / \mathrm{cm}^{3}$ and the value of the density 
Table 1. Density values of intrusive rocks in the study area.

\begin{tabular}{lccccccc}
\hline Rock name & gneiss & $\begin{array}{c}\text { Alkaline } \\
\text { syenite }\end{array}$ & $\begin{array}{c}\text { Nepheline } \\
\text { syenite }\end{array}$ & granodiorite & dolerite & tonalite peridotites \\
\hline $\begin{array}{c}\text { Density } \\
\text { range/ } \\
\text { g/cm }\end{array}$ & $2.60-2.90$ & $2.60-2.95$ & $2.53-2.70$ & $2.67-2.79$ & $2.70-3.50$ & $2.62-2.96$ & $2.78-3.37$ \\
$\begin{array}{c}\text { Mean } \\
\text { density } \\
\text { value/ } \\
\text { g/cm }\end{array}$ & 2.75 & 2.78 & 2.61 & 2.73 & 3.10 & 2.79 & 3.08 \\
\hline
\end{tabular}

of the surrounding sedimentary formations to the south-west mainly limestones and sandstones with mean densities of $2.55 \mathrm{~g} / \mathrm{cm}^{3}$ and $2.35 \mathrm{~g} / \mathrm{cm}^{3}$ respectively, the $3 \mathrm{D}$ model possibly consist of an intrusive igneous body (gneiss, granodiorite) with a density estimated at about $2.74 \mathrm{~g} / \mathrm{cm}^{3}$ surrounded by other metamorphic formations to the north-east and sedimentary formations to the south-west. The density contrast between this body and the sorrounding formations varies from $0.07 \mathrm{~g} / \mathrm{cm}^{3}$ to $0.39 \mathrm{~g} / \mathrm{cm}^{3}$.

According to [10], the intrusive rocks emplaced in the Nyong Unit were linked to an overstretching phase just before the Panafrican Orogeny. It is therefore possible that this overstretching phase coupled with the high tectonic activity and the regional field stress present in the area [4] caused the dislocation of this dense intrusive block from the broader intrusion suspected in the area [19]. The further characterization and modelling of this broader structure will ensure a better understanding of the structural layout of the Cameroon coastal basins made up of the Douala and Kribi-Campo sub-basins.

\section{Conclusion}

The analysis of the third order residual anomaly map and the superposition of horizontal gradient maxima from the residual anomaly and its upward continuation at several heights shows quasi-circular disposition of many maxima indicating the presence of a dense intrusive body in the Kribi area. The multi-scale analysis of the maxima of the horizontal gradient of the third order residual anomaly led to the location of this body at a depth to bottom ranging $0.5 \mathrm{~km}$ and $5.0 \mathrm{~km}$. The power spectrum method used gave the depth to the top from the surface at $0.5 \mathrm{~km}$ and $1.6 \mathrm{~km}$ and to a mean depth to the bottom of $3.6 \mathrm{~km}$. The 3D model obtained using the GRAV3D software and taking into account the results provided by the two previous methods, shows a block with part of its top located at $0.5 \mathrm{~km}$ and other sections located at about $1.5 \mathrm{~km}$. Its bottom lies at a depth ranging from $4.8 \mathrm{~km}$ to $5.2 \mathrm{~km}$. The identified body of density $2.74 \mathrm{~g} / \mathrm{cm}^{3}$ which is surrounded by other lower density metamorphic formations to the north-east and sedimentary formations to the southwest suggests that it is an igneous intrusion. The observation of the shape of this body coupled with the results obtained by [19] leads to the observation that this body is part of a 
broader intrusion extending northwards. A further 3D modelling and characterization of this broader structure can lead to a more profound understanding of the tectonic origin and structural layout of the Cameroon coastal basins namely the Douala sub-basin and the Kribi-Campo sub-basin. The interpretation of the 3D model of the Kribi-Campo intrusive body and the discontinuities surrounding it could serve as a guide in the investigation and exploitation of oil, gas and mineral sources in the study area, facilitating the location of points favorable to their existence. This result could also serve as a guide in the identification of risk areas. Apart from this, further studies could be carried out to identify the types of minerals that can be found in this massive and dense igneous intrusion. It is also important to determine in further studies the thickness of this basin in order to know the extent to which this body influences the sedimentary cover and its impact on potential mining resource in the area.

\section{Acknowledgements}

We greatly appreciate constructive and insightful comments of reviewers whose remarks and critique have led to a significant improvement of the work. We equally want to thank the team of Geophysicists from the Laboratory of Physics of Earth's Environment of the University of Yaoundé 1 who made the data acquisition campaign possible, Prof. Njandjock Nouck Phillipe, Dr. Evariste Ngatchou and Mr. Abate Marcel are gratefully acknowledged for leading this campaign.

\section{References}

[1] Brownfield, M.E. and Charpentier, R.R., (2006) Geology and Total Petroleum Systems of the West-Central Coastal Province (7203), West Africa. US Geological Survey Bulletin 2207-B. https://pubs.usgs.gov/bul/2207/B/

[2] Ntamak-Nida, M.J., Bourquin, S., Makong, J.C., Baudin, F., Mpesse, J.E., Ngouem, C.I., Komguem, P.B. and Abolo, G.M., (2010) Sedimentology and Sequence Stratigraphy from Outcrops of the Kribi-Campo Sub-Basin: Lower Mundeck Formation (Lower Cretaceous, Southern Cameroon). Journal of African Earth Sciences, 58, 118. https://doi.org/10.1016/j.jafrearsci.2010.01.004

[3] Tadjou, J.M., Nouayou, R., Kamguia, J., Kande, H.L., Manguelle-Dicoum, E. (2009) Gravity Analysis of the Boundary between the Congo Craton and the Pan-African Belt of Cameroon. Austrian Journal of Earth Sciences, 102, 71-79.

[4] Owona Angue, M.L.C., Tabod, C.T., Nguiya, S., Kenfack, J.V. and Tokam Kamga, A.P. (2013) Delineation of Lineaments in South Cameroon (Central Africa) Using Gravity Data. Open Journal of Geology, 3, 331-339. https://doi.org/10.4236/ojg.2013.35038

[5] Manguellé-Dicoum, E., Bokosah, A.S. and Kwende-Mbanwi, T.E. (1992) Geophysical Evidence for a Major Precambrian Schist-Granite Boundary in Southern Cameroon. Tectonophysics, 205, 437-446. https://doi.org/10.1016/0040-1951(92)90447-E

[6] OwonaAngue, M.L.C., Assembe, S.P., Njingti, N., Ngoh, J.D., NdougsaMbarga, T., Kue Petou, R.M. and Bisso, D. (2016) Determination of the Structural Lineaments in the Kribi-Campo-Ma'an Area from a Multi-Scale Analysis of Gravity Data Using the HGM and Euler 3D Deconvolution Approaches. International Journal of Geos- 
ciences, 7, 1122-1143. https://doi.org/10.4236/ijg.2016.79085

[7] Minyem, D. and Nedelec, A. (1990) Origin and Evolution of the Eseka Gneisses (Cameroon). Archean TTG Reworked in the Panafrican Mobile Belt. 15th Colloquium of African Geology, 2, 21-24.

[8] Toteu, S.F., Penaye, J. and Poudjom Djomani, Y.H., (2004) Geodynamic Evolution of the Pan-African Belt in Central Africa with Special Reference to Cameroon. Canadian Journal of Earth Sciences, 41, 73-85. https://doi.org/10.1139/e03-079

[9] Owona Angue, M.L.C., Nguiya, S., Nouayou, R., Tokam Kamga, A.P. and Manguelle-Dicoum, E. (2011) Geophysical Investigation of the Transition Zone between the Congo Craton and the Kribi-Campo Sedimentary Basin (South-West Cameroon). South African Journal of Geology, 114, 145-158. https://doi.org/10.2113/gssajg.114.2.145

[10] Vicat, J.P., Leger, J.M., Nsifa, E., Piguet, P., Nzenti, J.P., Tchameni, R. and Pouclet, A. (1996) Distinction au Sein du craton congolais du Sud-Ouest du Cameroun, de deux épisodes doléritiques initiant les cycles Orogéniques éburnéen (Paléoprotérozoïque) et Pan-Africain (Néoprotérozoïque). Compte Rendu de l'Académie des Sciences, 323, 575-582.

[11] Ngoumou, P.C., Ndougsa Mbarga, T., Assembe, S.P. and Kofane, T.C. (2014) Evidence of Iron Mineralization Channels in the Messondo Area (Centre Cameroon) Using Geoelectrical (DC \& IP) Methods: A Case Study. International Journal of Geosciences, 5, 346-361. https://doi.org/10.4236/ijg.2014.53034

[12] Tchameni, R., Mezger, K., Nsifa, E.N. and Pouclet, A. (2001) Crustal origin of Early Proterozoic Syenites in the Congo Craton (Ntem Complex), South Cameroon. $\mathrm{Li}$ thos, 57, 23-42. https://doi.org/10.1016/S0024-4937(00)00072-4

[13] Rosendahl, B.R. and Groschel-Becker, H. (1999) Deep Seismic Structure of the Continental Margin in the Gulf of Guinea: A Summary Report. In: Cameron, N.R., Bate, R.H. and Clure, V.S., Eds., The Oil and Gas Habitats of the South Atlantic, Geological Society, London, 153, 75-83. https://doi.org/10.1144/GSL.SP.1999.153.01.05

[14] Burke, K. (1969) Seismic Areas of the Guinea Coast Where Atlantic Fracture Zone Reach Africa. Nature, 222, 655-657. https://doi.org/10.1038/222655b0

[15] Perez-Diaz, L. and Eagles, G. (2014) Constraining South Atlantic Growth with Seafloor Spreading Data. Tectonics, 33, 1848-1873. https://doi.org/10.1002/2014TC003644

[16] Tokam, K.A.P., Tabod, C.T., Nyblade, A.A., Julia, J., Wiens, D.A. and Pasyanos, M. (2010) Structure of the Crust beneath Cameroon, West Africa, from the Join Inversion of Rayleigh Wave Group Velocities and Receiver Functions. Geophysical Journal International, 183, 1061-1076. https://doi.org/10.1111/j.1365-246X.2010.04776.x

[17] Collignon, F. (1968) Gravimétrie et reconnaissance de la République Fédérale du Cameroun. ORSTOM, Paris, 35 p.

[18] Nsifa, E.N. (2005) Magmatisme et évolution géodynamique de l'Archéen au Protérozoïque de la bordure nord-ouest du craton du Congo (complexe du Ntem) au Sud-Ouest Cameroun. Thèse Doctorat d'Etat, Université de Yaoundé I, Yaoundé, $248 \mathrm{p}$.

[19] Koumetio, F., Njomo, D., Tabod, C.T., Noutchogwe T.C. and Manguelle-Dicoum, E. (2012) Structural Interpretation of Gravity Anomalies from the Kribi-Edea Zone, South Cameroon: A Case Study. Journal of Environmental \& Engineering, 9, 664673. https://doi.org/10.1088/1742-2132/9/6/664

[20] Archibald, N.J., Gow, P. and Boschetti, F. (1999) Multiscale Edge Analysis of Poten- 
tial Field Data Exploration. Geophysics, 30, 38-44.

[21] Cordell, L. and Grauch, V.J.S. (1985) Mapping Basement Magnetization Zones from Aeromagnetic Data in the San Juan Basin, New Mexico. In: Hinze, W. J., Ed., The Utility of Regional Gravity and Magnetic Anomaly Maps, Society of Exploration Geophysicists, 181-197. https://doi.org/10.1190/1.0931830346.ch16

[22] Cordell, L. (1979) Gravimetric Expression of Graben Faulting in Santa Fe Country and the Espanola Basin, New Mexico. In: Ingersoll, R.V., Ed., Guidebook to Santa $\mathrm{Fe}$ Country, New Mexico Geological Society, Socorro, 59-64.

[23] Spector, A. and Grant, F.S. (1970) Statistical Models for Interpretation Aeromagnetic Data. Geophysics, 35, 293-302. https://doi.org/10.1190/1.1440092

[24] Gerard, A. and Debeglia N. (1975) Automatic Three-Dimensional Modeling for Interpretation of Gravity or Magnetic Anomalies. Geophysics, 40, 1014-1034. https://doi.org/10.1190/1.1440578

[25] Bhattacharryya B.K. and Leu, L.-K. (1975) Spectral Analysis of Gravity and Magnetic Anomalies Due to Two-Dimensional Structures. Geophysics, 40, 993-1013. https://doi.org/10.1190/1.1440593

[26] Radhakrishna, I.V. and Krishnamacharyulu, S.K.G., (1990) Polyfit: A Fortran 77 Program to Fit a Polynomial of Any Order to Potential Field Anomalies. Journal of the Association of Exploration Geophysicists, 11, 99-105.

[27] Maurizot, P., Abessolo, A., Feybesse, J.L., Johan, V. and Lecomte, P., (1986) Etude et prospection minière du sud- ouest Cameroun. Synthèse des travaux de 1978 à 1985. Rapport, BRGM, $274 \mathrm{p}$.

[28] Telford, W.M., Geldart, L.P. and Keys, D.A. (1976) Applied Geophysics. Cambridge University Press, Cambridge, 860 p.

Submit or recommend next manuscript to SCIRP and we will provide best service for you:

Accepting pre-submission inquiries through Email, Facebook, LinkedIn, Twitter, etc. A wide selection of journals (inclusive of 9 subjects, more than 200 journals)

Providing 24-hour high-quality service

User-friendly online submission system

Fair and swift peer-review system

Efficient typesetting and proofreading procedure

Display of the result of downloads and visits, as well as the number of cited articles

Maximum dissemination of your research work

Submit your manuscript at: http://papersubmission.scirp.org/

Or contact ijg@scirp.org 